\title{
Challenge of Ethnicity, Politics by Identity and Prebendalism to Security and Social Stability in Nigeria, 1999 to 2015
}

\author{
Chinedu N. Mbalisi \\ http://dx.doi./org/10.4314/ujah.v18i3.4
}

\begin{abstract}
Nigeria is plagued by avalanche of challenges. Prominent among them are issues of ethnicity, politics by identity, security, religious cleavages, corruption and nepotism, and prebendalism to mention a few. These factors have continued to generate tensions that sap the country of its vitality. They have created unhealthy competition among different Nigerian elites mainly, those from the three largest ethnic groups centered on national economic control and political leadership. The continued dominance of the country's national life by the Hausa-Fulani, the Igbo and Yoruba, and the ensuing conflict among political elites of the diverse groups, distort and threaten socio-economic development, national security and disturb peaceful co-existence among Nigerians. Ethnic and religious cleavages have assumed terrorist dimension that interrupt economic and social stability. Hence, government ineptitude, manipulations and growing Islamic and Christian assertion seem to heighten violence between adherents of the two religions in the country. This paper essays on the challenges of security and social stability. It argues that amongst the numerous challenges to security and social stability in Nigeria, ethnicity, politics by identity and prebendal politics are directly responsible. The persistence of these grim issues makes the country trade the tumbled pathway to disintegration heightened state of insecurity and social instability.
\end{abstract}


Keywords: ethnicity, politics by identity, corruption, prebendalism, security and social stability.

\section{Introduction}

Since independence, Nigeria as a sovereign nation-state with its multi-ethnic and multi-religious composition is plagued with avalanche of chronic challenges. In her 53 years of independence efforts at solving these numerous teething problems hindering her national growth and development has yielded paltry results. Especially, ethnic-political and religious problems have remained constant features of the nation's political and economic life. More so, the issues of ethnicity, corruption, politics by identity and prebendalism have compounded these challenges and have put the nation in a state of near comatose. As a result of the negative effects of these issues, efforts at building a united nation has been chequered. It is truism that politics in Nigeria is synonymous with ethnicity, as it has continuously and permanently featured in the nation's political life. This has given rise to "politics by identity" as each ethnic group in Nigeria strives to project its ethnic interest first, ahead of a collective Nigerian interest.

The role of ethnicity in the unnecessary Nigeria-Biafra civil war (1967-1970) will not be over emphasized, consequently, postcivil war Nigeria has been characterized by the politicization of ethnicity. The political, economic, socio-cultural and sundry activities in Nigeria have since been conducted along ethnic leanings. For instance, Ogugua asserts, "that of the 1989 Constitutional Conferences was inspired by sophistry and chicanery irrespective of the caliber of person who attended it and the beautiful resolutions made" (Ogugua, 109). The decisions reached at the conference reflected the ethnic foundation of the 
participants and the sentiment expressed showed their love first as members of their ethnic groups than Nigerians. The situation exposed the cosmetic nature of the desired Nigerian unity. The key issue at play in this situation has been ethnicity. Tahir concurs that, "the draft of the constitutional conference is more of a mechanical charter of ethnic groups rather than that of a nation with common destiny and will (Tahir, 109).

Obviously, the challenges of ethnicity, religious fanaticism, corruption, politics by identity, and practice of prebendalism have created destructive security challenges and social instability bedeviling Nigeria's fledgling democracy. The struggle for political power, control and distribution of the country's resources amidst other agitations, has continued to heighten insecurity and promote divisive tendencies. It is in search of solution for the things that have fallen apart in Nigeria that such concepts like; Federal Character, Quota system, Zoning Formula, Oil producing and Non-oil producing states dichotomy, among many others were introduced. Despite all efforts at ensuring a peaceful Nigeria, security challenges and social instability have persisted, and have even assumed violent terrorist dimension in recent times. These situations have become increasingly worrisome, leaving Nigerians at home and in Diaspora disillusioned.

The questions making the rounds among scholars and Nigerians are: why has insecurity and social instability continued unabated in spite of efforts geared towards a peaceful and harmonious Nigeria? Why has the gap between the different ethnic groups in Nigeria continued to widen, democratic government notwithstanding? Does it mean that the leaders are not getting it right? What are the implications of these precarious situations on the nation's polity? What are the hopes towards combating these 
challenges threatening the peace, unity and development of Nigeria?

The thrust of this inquiry is to examine the questions raised, develop a conceptual framework, and show how ethnicity poses a challenge to security \& social stability in Nigeria. It also discusses how the practice of prebendalism and politics by identity threaten security and social stability in the country. Its concluding remarks are interspersed with suggestions towards confronting these challenges.

\section{Conceptual Framework}

The concepts that would be clarified especially with regard to their usage and meaning in this inquiry include ethnicity, politics by identity, corruption, prebendalism, security and social stability. These concepts would be examined in relation to their application to the socio political context of the Nigerian situation. Seemingly, these factors collectively contribute to the extant threat to security and social stability that impede national peace, unity and development.

Ethnicity: Conceptually is a social phenomenon associated with interactions among members of social formations distinguished by the communal character of their boundaries. The most important communal factor is culture, particularly language. As social formations ethnic groups are however not necessarily homogeneous entities culturally speaking. Minor cultural and linguistic differences may exist within the groups, forming the basis for the delineation of sub-groups. More importantly, there is the possibility of occupational and class differentiation. Ethnicity is behavioural in form and conflicting in content. There are certain attributes of ethnicity, especially, as it could be identified in 
Nigeria. Nnadozie states that ethnicity can only exist in a heterogeneous polity that is, geo-political entity consisting of diverse ethnic groups. It is the relationship between the ethnic groups within the same political society that produce ethnicity (Nnadozie 136).

However, many scholars have expressed similar views on ethnicity, portraying it in positive and negative sense. It has been seen as a social problem in Nigeria. Chinua Achebe writes of ethnicity as "discrimination against a citizen because of his place of birth" (Achebe 8). For Nnoli, it is a social group within a cultural and social system that claims or is accorded special status on the basis of complex, often variable traits including religious, linguistic, ancestral or physical characteristics (Nnoli, 30). Irukwe perceives ethnicity as a belief in superiority of one's own cultural group and corresponding hatred or misunderstanding of other such groups (Irukwe, 89).

Ethnicity does not always demand for sovereign status or the use of state apparatus to the exclusion of others. However, Nnadozie contends that,

when an ethnic group within a polity feels threatened, oppressed, and unsafe or denied its own share of the common wealth especially, those within its immediate geographical areas, its relations with other ethnic groups could be characterized as nationalistic (Nnadozie, 136).

In most cases, ethnicity tends to be characterized by a common consciousness that makes it exclusive in relation with others within the polity. Social relations may be based on rejection or acceptance on linguistic-cultural leanings. Hence, these result in inter-ethnic discrimination expressed in marriages, jobs, housing, admission into educational institutions, political appointments, award of 
contracts, formation of political parties, and citing of industries, among others. Apparently, inter-ethnic conflict thrives as the process is characterised by nepotism, corruption, politics by identity, and prebendalism. Hence merit is sacrificed on the altar of ethnic chauvinism and solidarity. Consequently, unhealthy interethnic competition and rivalry and struggle for the control of political and economic resources intensifies in a society where inequality, disregard for fundamental human rights and rule of law are accepted as natural, and wealth acquisition extolled and esteemed. Under this type of situation as Nnoli opined,

It becomes possible for an ethnic group to adopt aggressive behaviour and hostility towards the other ethnic groups as a means of limiting competition in its favour. Consequently, demonstrations, rioting and other forms of violent agitations become "instruments" in the relationship among the different ethnic groups (Nnoli, 8).

This situation in Nigeria has assumed an unprecedented terrorist dimension.

Politics by identity: This is another concept that deserves consideration. First, each of the three words; politics, by, and identify, would be explained and second, the three would be taken collectively in their usage in this inquiry. What then is politics? A study of politics involves analysis of government and its working as well as its political organization as a process of regulating its activities in a society.

Politics as defined by the Oxford Advanced Learner's Dictionary, explains the activities involved in getting and using power in public life and being able to influence decisions that affect a country or a society: matters concerned with getting or 
using power within a particular group or organization (Hornby, 899). Historically, Ogugua writes that early scholars like Aristotle, Plato, Hobbes, Locks etc have used the concept politics. Politics as some scholars testified is as old as man, for man is a political animal. It was at Athens that politics was given a lot of concern; where the life of the citizen was divided into contemplative and active life and it is reserved for the free men (Ogugua 115). Janet in Ogugua sees politics as "that part of the social science which treats the foundations of the state and the principles of government". Ogugua quickly adds that it is that very science and art which studies the conditions essential for the existence and development of the state (114). Hence politics is of the state and belongs to it, and the state is a nation or nation-state.

The term "identity" in its dictionary word meaning is "who or what somebody/something is"; the characteristic feelings or beliefs that distinguishes people from others" (Hornby, 593). According to Erikson in Morgan, "identity refers to the "who am I?" and "what am I going to do with my life?" (Morgan, 350) Again, Erikson explains identity as "a voice inside which speaks and says; "this is the real me". It has elements of certainty and distinctness in its analysis and understanding of individual's behaviour and traits. Erikson had concluded that identity formulation (as) a process by which individual judges himself in the light of what he perceives to be the way in which others judge him in the light of how he perceives himself in comparison to them and to types that have become relevant to him. (114)

Usually people do not concern themselves with the issue of identity but do so when boundaries and behavioural implications of our social categories are contested. Consequently, as David Laitin states, "social identities are distinct from personal identities, and they are built from available categories that both divide and unite 
people in a society. Hence there exist different forms of identities inter alia; national identities, racial identities, religious identities, and hometown identities" (David, 115). David therefore concludes that indentifies are categories of membership that are based on all sorts of typologies- gender, race, class, personality, caste. People are limited by, but they are not prisoners of their genes, their physiognomies, and their histories in settling on their own indentifies. And if powerful social factors motivate identity exploration- as they seem to do in our age- it is the constructivists' face of identity that seems the more real". (115)

Politics by identity like identity politics involve political arguments that focus upon the self interest and perspectives of self-identified social interest group and way in which people's politics may be shaped by aspects of their identify through race, class, religion, gender, ethnicity, ideology, nation, sexual orientations, profession, hobby or any other loosely correlated yet simple to intuit social organization. However, what appears to be crucial about politics by identity is the experience of a people or group to oppression and the possibility of a shared and more authentic or self determined alternative. This implicit ontology in part explained the persistent historical failure of liberal democracies to achieve anything more than token inclusion in power structures for members of marginalised groups. Cudd noted that,

individuals are oppressed by virtue of their relationship in a particular social group-that is a collective who members have relatively little mobility into or out of the collective, who usually experience their membership as involuntary, who are generally identifies as members by others and whose opportunities are deeply shaped by the relation of 
their group to corollary groups through privileged and oppression (Cudd, Wikipedia).

From the foregoing, ethnicity and identity combine to influence politics in Nigeria. Hence, scholars talk of political ethnicity in political life of Nigeria. The high level of corruption and the practice of prebendalism are the most common features causing insecurity and social instability in Nigeria. Let us look at corruption and prebendalism briefly.

Corruption and prebendalism are two factors that have negatively affected security and social stability in all fabrics of Nigeria. They are the two dangerous cankerworms that have eaten deep into the psyche of Nigerians- both the high and might, and the poor and lowly in the society. There are so many arouse views and definitions by various people on corruption. In our attempt at defining corruption, we would adopt a few explanations offered by notable institutions. According to the United Nations Development Programme (UNDP),

Corruption is the misuses of public power, office or authority for private benefit through bribery, extortion, influences pedaling, nepotism, fraud...or embezzlement. Although corruption is often seen as a "sin" of government, it also prevails in the private sector" (UNDP, 7).

Another definition adopted is the one offered by Blacks Law Dictionary. It sees corruption as;

The act of doing something with an intent to give some advantage inconsistent with official duty and the rights of others; a fiduciary's or office to procure some benefits either personally or for someone else, contrary to the rights of others (397). 
From the above perspectives, it is obvious that corruption involves that use of public office to amass illegal wealth for personal use and that of relatives. This act of corruption by Nigerian leaders and politicians results in the practice of prebendalism in the country's political life.

The conceptualization of prebendalism as a phenomenon in the political system of Nigeria is apt. Prof Richard Joseph in his book, Democracy and Prebendal Politics in Nigeria, explained that it derives from feudal Europe where members of the clergy felt entitled by right to the revenue of a cathedral. Prof. Richard traces its rise and application in politics by Nigerian leaders at the time. On the concept, he explained that;

Prebendalism is the disbursing of public offices and state rents to one's ethnic clients. It is an extreme form of clientelism that refers to the practice of mobilizing cultural and other sectional identities by political aspirants and office holders for the purpose of corruptly appropriating state resources. Prebendalism is an established pattern of political behaviour that justifies the pursuit of and the use of public office for the personal benefit of the officeholder and his clients. (Richard, 55)

In the political practice of prebendalism, the official public purpose of the office becomes a secondary concern. In a similar perspective, Mark Kesselman et al write thus:

As with clientelism, in a prebendal political structure, office holder's clients compromise specific set of elites to which he is linked, typically by ethnic or religious ties, and this linkage is key to understanding the concept (Kesselman, 393). 
Furthermore, Prof. Richards states that, there are two sides involved in prebendalism, the office-holder and the client and expectations of benefits by the clients (or supporters) perpetuate the prebendal system in a pyramid fashion with a "Big Man" or "godfather' at the top and echelons of intermediate 'Big Men' and clients below (56). Utilizing the concept of prebendalism Prof. Joseph incisively and perceptively explicated the rise and fall of the Second Republic in terms of the illegal privatization of the public officers and resources by those who have otherwise sworn to uphold the law and promote the public good.

Segun Ayobolu asserts;

This kind of criminal diversion of public resources for selfish private ends starred the polity of funds for development, increased poverty, and inequality and intensified and unhealthy rivalry and competition for public office that triggers pervasive instability election rigging, violent conflicts and ultimately, coups and social instability in Nigeria (Ayobolu, 24).

Hence, prebendalism in contemporary Nigeria politics could be described to be on the increase. One could rightly talk unequivocally of "rise and rise" of prebendalism in recent times. As a consequence, the implication of prebendalism in Nigeria is the massive threat to security and social stability prevalent in Nigeria.

Nonetheless, the concepts security and social stability: are two variable factors that are some worth inseparable. A brief insight into security and social stability would suffice. Security as a social phenomenon is reflective of safety. The Dictionary meaning of the term include; "the activities involved in protecting a country, building or person against attack"; it is also the act of 
protecting against something bad that might happen in the future; the state of being happy and safe from danger or worry (Hornby, 1063). Simply speaking, security involves the ability to safeguard people, life and property from crime, danger or attack. Hence, protection against attack from without or subversion from within is a matter of national interest. In Nigeria, security challenge has remained pressing problem in the country. Therefore, the absence of effective security of the citizens hampers social stability.

In a similar vein, social stability refers to the ability to ensure conditions favourable for human co-existence. It is the existence of stable environment that guarantees the people the confidence to co-exist and co-habit without fear, tension and violence. Social stability is based on the maintenance of current and classic social pariahs and systems. According to Gubin, social stability is "the actual observance of governmentally-formalized, regulated and enforced laws, rules, and norms for societal relations" (Gubin 89). In order words, a high-stability society is one in which a large number of governmentally-formalised, regulated and enforced laws, rules, and norms are observed. Likewise, a less stable society is one in which a small or nonexistent percentage of governmentally-formalized, regulated, and enforced laws, rules and norms are observed.

Social stability guarantees social control through the strict observance of the rule of law to ensure favourable environment and conditions needed for social change, peace, socio-political and economic development. It could then be argued that ethnicity; politics by identity and prebendal practices has remained massive and persistent challenges to security and social stability in. 


\section{The Incidence of Ethnicity, Politics by Identity and Prebendalism in Nigeria}

The concern of this sub-section is to put fore, through different incidences how ethnicity, politics by identity and prebendalism, affect security and social stability. It has been at the base of most political and economic conflict in Nigeria leading to insecurity and social instability. It has played more vicious roles since the colonial and post-colonial contact among Nigerians. Nnoli observed that "colonial and urban origin of ethnicity becomes clear when it is realized that the phenomenon cannot exist unless individuals from different communal groups are in contact" (Nnoli 36). When the British amalgamated the Southern and Northern protectorates for convenience, they committed a great blunder which has enrobed and enveloped Nigeria in a great debacle and quagmire.

This has ceaselessly fermented problems which express itself in ethnic, religious and political crisis since independence. The West had enforced the ideology of capitalist mode of product whereas the Nigeria minds were ill-prepared for it. The new classes created try this new ideology substituted those of the indigenous people- largely communal. Nnonyelu writes that, "the development of colonial cities as centers of trade, commence and administration; the monetization of our economy, and the introduction of taxation compelled rural dwellers to relocate to the cities in large numbers to eke out a living and be able to pay the white man's tax. To the chagrin of the new rural migrants, rural woes are even better than urban miseries" (Nnonyelu, 149) in an elaborate explanation of the incidence of ethnicity in post-colonial Nigeria, Ogugua writes that: 
Post-colonial basis of ethnicity, has a multi-quam plural dimension viz. the impact of socio-economic competition, secretary of resources in the urban setting, inequality in the colonial Urban setting, the myth of cultural diversity, the technique of divide and rule which occasioned marginalization, lack of economic unity, relevant precolonial differences, inter-ethnic struggle for political power, factionalism within the elite and privileged class of Africans; regionalization of national health, Inter-regional struggle for federal resources, rivalry in the provision of emanating, intemperate utterances (this caused Abiola the presidency and led to his death); growth in socio-economic competition, ethnic violence etc. (Ogugua 120).

It would be recalled that original relations among the groups were smooth and enriching. But as Sofola observed, interactions between them were so positive that intergroup marriage was fairly common. As time went on, the relations became strained as the groups struggled for the scarce and limited but unequally distributed resources (Sofola 1970).; Nnoli in a similar vein, writes that "as more people joined the competition for resources, the spatial area of their search for resources widened considerably to include not only members of different clans, villages and districts, but increasingly, members of different linguistic groups" (Nnoli 104). This situation has been the socio-economic basis for the contemporary ethnicity and politics by identity experienced in Nigeria today.

Nonetheless, the thirst for power between 1945 and 1959 was characterized by intrigues, The political leaders at the time were more concerned with building both political and financial empires, consequently, the spirit of nationalism gave way to 
regionalism and ethnic politics. During the period Dr. Nnamdi Azikiwe and Awolowo dominated the political scene. Zik as Ogugua observed, 'was a colossus due to Awo's absence for sometime in the politics of Nigeria. He joined the National Council of Nigerian Citizens (NCNC), made up of two trade union, two political parties, eight professional bodies, eleven social clubs and 101 tribal unions.

The Yoruba in the NCNC were afraid of Igbo domination and denied Zik the opportunity he would have gotten with ease to represent the Western House in the Federal House in 1951. This practice of ethnicity and politics by identity pushed Zik far and he went home and expelled Eyo Ita in 1952 from the NCNC, Eyo and his people left the party (Ogugua, 121). This situation was to play out in subsequent elections and had pulled Nigeria into the Nigeria-Biafra civil-war. At the post independent era, most if not all the political parties has maintained the tilt towards ethnic groups, and the politics played at the time was first by ethnic identify and second for Nigeria. For instance, the National Party of Nigeria (NPN), the Unity Party of Nigeria (UPN) and the Nigerian Peoples Party (NPP), were all tribal parties initially. Each was formed by a clique of people from the North, West and East respectively.

As Ogugua pointed out, the case of Abiola M.K.O., a multi-billion naira businessman who negotiated with N.P.N to be its flag bearer in 1983 election and who sponsored the party was told that the presidency was not for sale and he decamped from the party (122). Even the results of the 1979 and 1983 elections exemplified the sentimentalism of ethnicity, politics by identify and the regional parochialism in our political life. Expectedly, the $3^{\text {rd }}$ and $4^{\text {th }}$ republic the same scenario has rife. The Peoples Democratic Party (PDP) is an ethnic organization from its 
operation, the Yoruba formed in their usual way Action for Democracy (AD) which was founded by Afenifere. All People's Party (APP) was the only party that was not on ethnic one. The Igbo did not form any party in the $4^{\text {th }}$ republic (Ogugua 122). It could then be stated that ethnicity and politics by identity are the bane of Nigeria. They have jointly dug the grace of underdevelopment, social instability and violent conflict in recent times. In a bid for each ethnic group to dominate politics in Nigeria, corruption, nepotism and prebendalism have been employed in the national politics. Hence, the numerous security challenges the nation is faced with. The massive negative impact of corruption in Nigeria politics has been succinctly provided by Academic Staff Union of Universities (ASUU) thus:

The phenomenon of massive corruption and its institutionalization as a key element of statecraft...goes for back in Nigeria's history (and) was a major excuse for the overthrow of the first republic and... of Gowons regime... Both Shagari's regime, Buhari's, Babangida's and Abacha's regimes have also been indicted (sic) regarding massive looting of public resources (p.19).

The denial of the June 2, 1993 presidential election was clearly a sow of ethnicity coupled with politic by identity. That election had been won by Chief M.K.O Abiola Yoruba man, but was annulled by Gen. Ibrahim Babangida a Hause/Fulani. Again, there was another display of ethnicity and politics by identify in 2003. During the Jos convention Ibrahim Babangida and his cabal maneuvered and gave the PDP presidential ticket to Obasanjo instead of Ekwueme who was favourably tipped to pick the ticket. The same man- Babangida and his clique found it uncomfortable with Obasanjo, and crisis upon crisis continually surface that 
made governance difficult (Ogugua, 123). It was obvious that Ekwueme was denied the ticked due to his ethnic group and then Obasanjo identified as an ex-military officer was preferred instead. However, Obasanjo's presidency signified a power shift from the North to the South. Shortly, the power shift combined with ethnicism, religious fanaticism and all forms of violent and terror related attacks to register their annoyance. Of course, when the election of leaders in Nigeria is determined by ethnic background rather than credibility, one should expect all manner of what constitutes bad government. The tendency for other ethnic groups to cry of marginalization becomes pronounced. This has been the case of the Igbo and most minority ethnic groups in Nigeria since the Second Republic up to the Fourth Republic. Political power during the era has been dominated by the Hausa/Fulani and Yoruba ethnic groups.

Nonetheless, during the military era, at least, the regimes of Babangida and Abacha, ethnic background were at the threshold of the institution of corruption and prebendalism in Nigeria. The official corruption at the time was so pronounced in Nigeria and the international scene. The democratic administration beginning 1999 appear to have borrowed corruption and prebendalism from the two past military regimes. Mark Kesselman et al write that

As a practice in Babangida and Abacha era, when official corruption occurred on an unprecedented scale, prebendalism deepened sectional cleavages and eroded the resources of state. It also discouraged genuinely productive activity in the economy and expanded the class of individuals who live off state patronages (Kesselman, 393).

Kesselman believes that corruption and prebendalism were rife during the regime of Babangida and Abacha. Hence, he provided a 
statistical data on the amount of resources involved during the period thus:

Corruption resulting from prebendal practices is blamed for the enormous overseas flight of capital into private accounts. It seems that the lion share of the $\$ 12.2$ billion windfall of the early 1990s was pocketed by Babangida and senior members of his regime. General Abacha continued this pattern and diverted at least \$5billion from the Nigerian central bank, and president Obasanjo and members of his administration are now being questioned for the disappearance of more than \$10billion into the power section alone. Transparency International regularly lists Nigeria among the most corrupt countries. (Kesselman, 393)

It is a truism that Nigeria is ranked amongst the most corrupt countries. This fact has always resulted from politics by identity practiced in the country by political leaders. The rate of corruption and prebendalism has retarded national development. Hence, the different ethnic militant groups that have emerged have continued to create security challenges that result in social instability, especially, since the return to democracy in 1999. The fact of the matter is Nigeria as an entity is bedeviled with avalanched of challengers arising from the political structure of the state. The trajectories of decolonization process and the turbulent nature of ethnic politics played in Nigeria has in no small means contributed to the rising profile of corruption, prebendalism and politics by identity in Nigeria. These are apparently exemplified in the unending struggle for power at the center the various ethnic nationalities amalgamated in 1914. 


\section{Implications of Politics by Identity Prebendalism Since 1999}

Since, the return of democracy in 1999, many ethnic-based militant groups and movements have taken advantage of renewed political freedoms to organize around their interests and to press the government to address their political, economic and social grievances. The extant political structure and politics by identity are partly to be blamed for the high rate of corruption in Nigeria. The presidential system of government practiced in the country is incurably expensive.

The uncanny behaviour and attitude of the Nigerian politician with their expanded appetite for conspicuous consumption worsens the situation. Therefore, poverty, greed, selfishness and the practice of prebendalism combines to exacerbate corruption. In turn, Nigerians are as it where, faced with all forms of security challenges and social insecurity in the polity. Since 1999, despite the media hype on the fight against corruption, it has continued to wreck the nation and sap it of its vitality. The establishment of the Economic and Financial Crimes Commission (EFCC) and the Independent Corrupt Practices and other related offences Commission ICPC) have not achieved any meaningful result. The reason is blamed on the decay in the system and unnecessary legal technicalities in the dispensation of justice perpetrated by the same power overlords. Hence since 1999-2007 under Obasanjo administration, corruption was a continuous feature of the era. Some examples would serve the purpose of buttressing this assertion.

According to a publication on, Thisday Newspaper, "between 1999 and 2007 when Obasanjo was Nigeria's president, the sum of $\$ 16$ billion is alleged to have been mismanaged by his government in the guise if finding a lasting solution to Nigeria's electricity supply problem (Thisday, 19). Again, an ASUU 
publication noted that neither the Halliburton scandal (involving an improper payment of $\$ 2.4$ million of principal officers of the Federal Inland Revenue Service (FIRS) in 2003), nor the $\$ 300$ billion allegedly meant for roads rehabilitation but misappropriation by his then Works Minister in 2003, was ever addressed.(ASUU, 3).

Since the end of Obasanjo's tenure in 2007, as Ota asserts, "the cohesiveness of the political elite has succeeded in protecting its corrupt members from prosecution and indeed taken corruption to more disturbing level. For instance, at a time when most Nigerians are living in penury, the political class is swimming in opulence. The president of the Nigeria Senate is reported to have earned a whooping 250 million quarterly as constituency allowance in 2010, while his deputy earned N150 Million per quarters or N50million per month (Ota, 207). Femi Orebe also observed that in the same year the senate voted N2.6 billion for local travels; N2.45 billion for overseas travels; N1.25 billion for security; N2.28 billion for contingency and N750 million for quest house for its president and his deputy (Orebe, 13).

The implication of this corrupt practices and prebendalism in Nigeria is perceived by Nigerians as the polity remained heated with political movements. Some mobilization has been peaceful, but many armed groups have also formed, at times with the encouragement or complicity of the mainstream political movements. For instance, Kesselman noted that "in the oilproducing regions these militia live off the pay they receive in providing security for oil "bunkering": illegal criminal networks (often including individuals in the oil industry, political leaders and the military) that tap into pipelines, siphon oil, and resell it on the black market (385). The Obasanjo government periodically responded to these incidents and other disturbances with excessive 
force. For instance, after the Ijaw militia killed several policemen in the village of Odi in late 1999, the military subsequently flattened the village, raping and killing many innocent people. Army units committed similar retaliatory atrocities in 2001 among villages in the Middle Belt state of Benue, when ethnic militias apparently killed several soldiers engaged in a Peace-Keeping Mission during on inter-ethnic dispute (Kesselman 385).

Ethic-based mobilization, including the activities of militias and vigilant groups has increased across the country since the transition to civilian rule in 1999. It is obvious that political leaders have sometimes built alliances with such groups and increasingly using them to harass and then kill political opponents. The largest of such groups, the movement for the Emancipation of the Niger Delta (MEND) that threatened to drive out foreign oil interests until their demands for a greater oil share was met. It was not until the tenure of Yar'Adua's that granted the militants "amnesty". Again, the emergence of Boko Haram -a seemingly faceless terrorist group based in Northern Nigeria has been linked to two issues. The first is political power shift from the North to the south, which ultimately has not solved the problem of terrorism in the North since power again returned to the North. The second is the increasing poverty and hardship in the North. The activities of this group have according to Mbalisi, has

generated enormous confusion, tension and serious security concerns in Nigeria, Africa and the world. The increased violent attacks by the sect on innocent Christians and Southerners, point to the fact that the current wave of ethno-political violent conflicts is as a result of power shift from the North to the South (Mbalisi, 164). 
The happenings appear as organized gang up against Nigeria's leadership headed by a Southerner and not truly religiously motivated attacks, but more of an ethno-political one. Their attacks point to ethnicity and the politics by identity prevalent in Nigeria's political structure. President Jonathan is simply identified as a Southerner, hence the attacks. There is no gainsaying the fact that the activities of the various ethnic-based militant groups are as a result of the in various roles of ethnicity, politics by identity, corruption and prebendalism.

These divisive practices overshadow certain positive aspects of sectional identities. For instance, association based on ethnic and religious affinities often serve as vehicles for mobilizing saving, investment and production, such as the informal credit associations. Sectional groups such as the Igbo- Ohaneze or the Yoruba- Afnifere or Hausa/Fulani- Arewa have at one time or the other have also advocated more equitable federalism and continued democratic development. These groups, which form an important foundation of civil society, have continued to provide a vehicle for political expression while also reflecting the divisive pressures of Nigeria's cultural pluralism. The manifestations of ethnicity, politics by identify, prebendalism, corruption and the likes have been at the base for the ever increasing level of security challenges and social instability prevalent in Nigeria today.

\section{Conclusion}

The concepts explained in this inquiry no doubt constitution great obstacles to national development. The high incidence of ethnicity, politics by identity are the key issues in Nigeria that have caused political leaders to engage in all manner of corrupt and prebendalism practices to sort their individual and group interests. 
Ethnic based associations such as MEND, MASSOB and the lethal Boko Haram terrorist group have emerged as a result of the continued political divides that are injurious to the security and social stability in Nigeria. The various military regimes and civilian administrations are guilty of ethnicity, politics by identify and prebendalism. They have all been indicted as being responsible in the height of unprecedented corruption that has been a feature of governments in Nigeria. The establishments of such anti-corruption agencies like the EFCC and ICPC have yielded little if any results at all. Rather, the incidence of these concepts in Nigeria is responsible for the underdevelopment, threat to peace and unity of Nigeria more than any other factor. Hence, it has resulted to the slow rate of development which has nailed Nigeria on the group described as "Less Developed" and "Third World" countries in the 21 st century.

Nonetheless all hope is not lost for Nigeria. Therefore as part of the ongoing efforts at finding solution to numerous challenges facing Nigeria, the paper hazards the following suggestions. If adopted, would assist in reducing and liberating the country from the shackles of ethnicity, politics by identity and prebendalism. Hence, Nigerians and Nigerian politicians must change in fundamental ways for democracy to become more stable and legitimate; The nation must turn from a system of politics dominated by "Big Men" for all intents and purposes, a competitive oligarchy- to a more real and sincere representative mode of politics that addresses the fundamental interests of the public: Nigerians must conclusively settle the national question and commit to political arrangements that accommodate the nation's diversity. In fact, Nigeria's present democratic government- the fourth republic must find ways of moving beyond prebendal political practices and develop a truly national political 
process in which mobilization and conflicts along ethnic, regional, and religious lines gradually diminish, and which can address Nigeria's true national crisis of corruption, poverty and underdevelopment. By so doing, Nigeria may be on the path top greatness and become a country where security and social stability guarantees national development. Nigeria's leaders must strive to exhume those factors that ensured peace and stability in indigenous pre-colonial Nigeria. Hence, we as Nigerians at home and in Diaspora, have a responsibility to recover, understand, promote and preserve those values that ensure harmony and respect for individual rights, not only because they represent a unique contribution to the history of ideas we share, but because renewal of respect for traditional values is the only lasting solution the political, economic and social problems that beset the Nigeria of our.

It suffices to provide some sublime solutions that could ameliorate these teething challenges of Nigeria. In the first instance, there is the obvious need to institutionalise a high level orientation of all Nigerians, especially the youths through the schools, churches and other social institutions. The orientation if properly planned and implemented, would provide in the near future, leaders who would rethink the political trajectories of Nigeria. Secondly, Nigeria could adopt positive political trends from countries like the United States where ethnicity is extant but serves positive purposes. For instance, there is no such issues as zoning formula, state of origin, quota system and national character etcetera in the US national life as such policies are inimical to comprehensive and equitable national development and sustainability.

In addition, the principles of true leadership and followership must be a virtue propagated, sort after and imbibed by 
all desiring to lead Nigeria. The cardinal ideals of a true servantleader should form the foundation and platform for the selection and election of leaders in Nigeria. More so, leaders in Nigeria must rethink the African democratic principles of communalism as a guiding light to leadership aspirations in Nigeria. The forceful imposition of western systems and over dependence and borrowing of strange and alien systems that are inimical to the African leadership heritage and systems must as a matter of fact be curtailed. If this is done, it will help preserve the original traditional Nigeria political systems such as the Igbo village democracy and its ability to enthrone equity, fairness and justice for all citizens. The afore mentioned African political virtues if reinvented in the stead of rampaging westernisation of the political systems in Nigeria, would help instill true African leadership potentials in individuals and the result may be salvaging the country from the dangers of prebendalism, ethnicity and politics by identity rampaging the political climate of Nigeria.

\section{Chinedu N. Mbalisi}

Department of History and

International Relations

Paul University, Awka

chidonzi@yahoo.com

\section{Works Cited}

1. Ogugua, Paul I., "Ethnic Nationalism and Identity Politics: The Nigeria Scene in Temporal Perspective" in Onuoha, J. and Okpoko, Pat U. ed., Ethnic Nationalism and Democratic Consolidation; Perspectives from Nigeria and the United States of America. Nsukka; Great AP Express Publishers Limited, 2004. print 
2. Ibrahim, Tahir, "Transformation of Nigeria Social and Moral Values" in Ogugua, P.I., "Ethnic Nationalism and Identity Politics..." pint

3. Nnadozie, O.U., Ethnic Nationalism and the National Question. The Nigerian Scene" in J. Onuoha and Pat U. Okpoko ed., Ethnic Nationalism and Democratic Consolidation..."

4. Achebe, Chinua, The Trouble with Nigeria. Enugu: Fourth Dimension Publishing Co. Ltd. 1983. print

5. Nnoli, Okwudiba, Ethnic Politics in Nigeria. Enugu: Fourth Dimension Publishing Co. Ltd., 1980. print

6. Irukwe, J.O. Nigeria: The Case for a Better Society, Enugu: Fourth Dimension Publishing Co. Ltd. 1996. print

7. Hornby, A.S Oxford Advanced Learners Dictionary of Current English, Oxford University Press, 2001.print

8. Morgan et al, Introduction to Psychology London: McGraw Hill International BR, Co. 1984.print

9. Erikson, E., Identify: Youth and Crisis. New York: Norton. 1995.print

David, Latin "Identify Choice under Conditions of Uncertainty" in Ogugua, P.I. "Ethnic Nationalism and Identify Politics...," in Ohuoha, J. and Okpoko, Pat U. Ethnic Nationalism...2004.print

10. "Fighting Corruption to Improve Governance", A Publication of the United Nations Development Programmes (UNDP). February, 1999, print

11. Garner, Bryan A, ed., Blacks Law Dictionary $9^{\text {th }}$ Edition, Minnesota: West Publishing Co., 200.print

12. "The State of the Nation", A Publication of the Academic Staff Union of Universities (ASUU) March, 2002. print 
13. Joseph, Richards, Democracy and Prebendal Politics in Nigeria: The Rise and fall of the Second Republic Cambridge University Press, 1987.print

14. Kesselman, Mark etal ed., Introduction to Comparative Politics; Political Challenges and Changing Agendas Fifth Edition. Boston: Wadsword, 2010. print

15. Ayobulu, Segun, "Prebendal Politics and the two Publics". The Nation. Lagos: November 21, 2012. print

16. Gubin, Oleg. I., etal, "Social Control Versus Social Stability a Conceptualization of Contradictory Goals and Hybrid Outcomes on Ethnic Relations, Consumers Satisfaction, and Entrepreneurship in the Former USSR", in NA-Advances in Consumer Research Vol. 20, eds. Leigh McAlister and Michael L. Rothschild, Provo, UT: Association for Consumer Research, 1993.print.

17. Nnonyelu, N. "Ethnicity, National Interest and National Integration in Nigeria" in Nigeria Socio-Political Development. Issue and Problems. 2001, print.

18. Sofola, J.A. "Some Aspects of Pre-crisis Inter-Ethnic Relations in Nigeria: The Yoruba Repatriates Social Relations in the former Eastern Region" in The Nigerian Journal of Economic and Social Studies Vol.12, No7, March 1970.print

19. Cudd cited "Identify Politics" in Stanford Encyclopedia of Philosophy First Publish July, 16, 2002, Substantive revision Tuesday February 7, 2012 in www.wikipedia free online. Retrieved April 19, 2013. internet.

20. "The Mysterious Okigbo Report" Thisday, Vol. 16, No 5811, Tuesday, March 22, 2011 print.

21. "The Position of the Academic Staff Union of Universities (ASUU) on the Problem of Corruption and the National 
Dialogue in Nigeria", Issued by the National Executive Council (NEC) of ASUU, May, 2005.print.

22. Ota, Ejitu N. "The Political Economy, of Corruption in Nigeria, 1999-2012", in Uzu: Journal of History and international studies (UJHIS) Vol. 3, No I Dec. 2012.print

23. Orebe, Femi, "this thievery in High places cannot continue" the Nation on Sunday, June 20, 2010.print.

24. Mbalisi, C.N., "Threshold of Ethno-Political Twist to Religious Conflict in Nigeria: In Historical perspective". In UZU. Journal of History and International Studies (UJHIS) Vol. 3, No1. Dec. 2012.print. 